\title{
Mellkasdeformitás okozta pulmonalis hipertónia oki kezelése
}

\author{
Csósza Györgyi', Valkó Luca², Baglyas Szabolcs², Losonczy György', \\ Lorx András², Gál János ${ }^{2 \star}$, Karlócai Kristóf ${ }^{\star}$
}

\author{
${ }^{1}$ Semmelweis Egyetem, Pulmonológia Klinika, Budapest \\ ${ }^{2}$ Semmelweis Egyetem, Aneszteziológiai és Intenzív Terápiás Klinika, Budapest \\ *Megosztott utolsó szerzők \\ Levelezési cím: \\ Dr. Csósza Györgyi, Semmelweis Egyetem, Pulmonológia Klinika, 1083 Budapest, Tömő utca 25-29. \\ E-mail: csoszagy@gmail.com
}

\begin{abstract}
A hypoxiához társult pulmonalis hipertónia hátterében tüdőbetegségek mellett egyéb, krónikus hypoxiát okozó extrapulmonalis betegségek is állhatnak. A kezelés elsődlegesen a hypoxia mérséklése, amely a pulmonalis hipertónia oki kezelését jelenti. A pulmonalis alapbetegség gyógyszeres kezelése mellett a megfelelő oxigén-szupplementáció biztosítása elengedhetetlen, amely nem minden esetben biztosítható csupán $\mathrm{O}_{2}$-terápiával. Esetünkben a pulmonalis hipertónia hátterében súlyos mellkasdeformitás, restriktív ventilációs zavar okozta légzési elégtelenség állt. A hypoxia tartós rendezésére ezért alacsony nyomástámogatással és magas $\mathrm{FiO}_{2}$-vel hosszú távú, otthoni noninvazív lélegeztetést indítottunk, amely hosszú távon is csökkentheti a pulmonalis hipertónia progresszióját.
\end{abstract}

Kulcsszavak: mellkasdeformitás, pulmonalis hipertónia, hypoxia, non-invazív lélegeztetés

\section{Treatment of pulmonary hypertension caused by chest wall deformity}

Chronic hypoxia associated pulmonary hypertension is most often caused by chronic lung disease but other extrapulmonary factors may also lead to its development. The treatment goal is to diminish hypoxia, which is causal treatment for pulmonary hypertension. In addition to pharmacological treatment of the pulmonary disease, adequate oxygen supplementation is essential, but is not always manageable solely with oxygen therapy. In our case the pulmonary hypertension was the consequence of respiratory failure caused by severe chest deformity and restrictive ventilation disorder. Therefore, long term home non-invasive ventilation with low pressure support and high $\mathrm{FiO}_{2}$ was used to decrease hypoxia; which might reduce progression of pulmonary hypertension in the long haul.

Keywords: chestwall deformity, pulmonary hypertension, hypoxia, non-invasive ventilation

\footnotetext{
Rövidítések

PH: pulmonalis hipertónia; PVR: pulmonalis vaszkuláris rezisztencia; mPAP: pulmonalis artériás középnyomás; COPD: krónikus obstruktív tüdőbetegség; NIV: noninvazív lélegeztetés; IV: invazív lélegeztetés; BIPAP S/T: kétfázisú légúti nyomást, spontán és időzített légvételeket biztosító kevert lélegeztetési mód; IPAP: belégzési légúti nyomás; EPAP: kilégzés légúti nyomás; RR: légzésszám; TI: belégzési idő; VT: légzési térfogat; TAPSE: tricuspidalis anulus szisztolés elmozdulása; IVRT: izovolumetriás relaxációs idő; JK lat S': jobb kamra laterális anulus szisztolés elmozdulási sebessége; TR: tricuspidális regurgitáció; APSP: becsült szisztolés pulmonalis nyomás; LVOT VTI: bal kamrai kiáramlás sebesség-idő intergál; FVC: forszírozott vitálkapacitás; $\mathrm{FEV}_{1}$ : forszírozott kilégzési volumen $1 \mathrm{sec}$ alatt; PEF: kilégzési csúcsáramlás; IVC: belégzési vitálkapacitás
} 


\section{Bevezetés}

Prekapilláris pulmonalis hipertóniában a pulmonalis artériákat érintő érfaleltérések következtében a pulmonalis vaszkuláris rezisztencia (PVR $>3 \mathrm{WU}$ ) és a pulmonalis középnyomás (mPAP $>25 \mathrm{Hgmm}$ ) emelkedése észlelhető, amely jobbszívfél-nyomásterhelést, majd jobbszívfél-diszfunkciót okoz. A 2015-ös ESC/ ERS-ajánlás szerint a patomechanizmus alapján csoportosítjuk a $\mathrm{PH}$ egyes formáit (1. táblázat) (1). A 3. csoportba tartozó hypoxiához társult $\mathrm{PH}$ hátterében a tüdő krónikus, parenchymát, vagy légutakat érintő betegségei és egyéb extrapulmonalis betegségek (alvási apnoe szindróma, alveoláris hypoventiláció) állhatnak. A hypoxia okozta vazokonstrikció jelentős szerepet játszik a PVR emelésében (2), de előrehaladott esetekben, ebben a csoportban is fennállhatnak az artériákat érintő strukturális eltérések. A hypoxiához társult $\mathrm{PH}$ előfordulásának gyakorisága az egyes kórképekben $5-40 \%$ is lehet. Jobbszívfél-katéterezéssel igazoltan, COPD-hez társult pulmonalis nyomásemelkedés enyhe-közepes mértékben (mPAP 26-45 Hgmm) 47,5\%ában, súlyos fokban (mPAP >46 Hgmm) az esetek $3,7 \%$-ában fordulhat elő (3). Idiopátiás pulmonalis fibrózisos betegek körében echokardiográfiával a pulmonalis nyomásemelkedés $16 \%$-ban igazolható (4). A pulmonalis hipertónia ezen csoportjában a terápia alapját az alapbetegség kezelése és a megfelelő oxigenizáció biztosítása jelenti, amely jelentős hemodinamikai javulást eredményezhet $(5,6)$.

\section{Esetismertetés}

44 éves férfi beteg súlyos mellkas- és gerincdeformitással született. Gyermekkorban több alkalommal kezelték légúti infekció, pneumónia miatt. 42 éves kora után több alkalommal intenzív osztályos kezelésre is szorult progrediáló nehézlégzés, pulmonalis infekció, globális légzési elégtelenség miatt. Noninvazív légzéstámogatás, gyógyszeres kezelés mellett a pulmonalis infekciója szanálódott, légzése javult. Otthonában inhalációs, hörgtágító-kezelést alkalmazott. A kórházi kezelések kapcsán készített echokardiográfiás vizsgálatok egyre kifejezettebb jobbszívfél-terhelést mutattak. Pulmonalis hipertónia kivizsgálása és további kezelése céljából irányították a beteget klinikánk pulmonalis hipertónia centrumába.

Felvételkor ismételten napok óta progrediáló nehézlégzésről számolt be, súlyos respiratórikus acidózist, globális légzési elégtelenséget és jobbszívfél-elégtelenséget észleltünk. Mellkas PA-röntgenképen a súlyos mellkas- és gerincdeformitás mellett jelentős cardiomegaliát is láttunk (1. ábra). Echokardiográfia a korábban már igazolt súlyos pulmonalis hipertóniát ekkor is mutatta (2. táblázat 1. oszlop). Infekcióra utaló klinikai és laboreltérés felvételkor nem volt. $A$ beteg klinikánk noninvazív lélegeztetési osztályára került. A globális légzési elégtelenséghez társult súlyos jobbszívfél-terhelés miatt a noninvazív lélegeztetés alacsony nyomástámogatással, magas oxigénáramlással indult (BIPAP S/T mód, IPAP: 11 vízcm, EPAP: 4 vízcm, RR:16/min, TI: $1,1 \mathrm{sec}$, VT: $450 \mathrm{ml}$ $\mathrm{O}_{2}: 8 \mathrm{I} / \mathrm{min}-\mathrm{FiO}_{2} 35 \%$ ). A kezelés mellett ventilációja javult, a vérgáz-leletben $\mathrm{pH}$-ja kompenzálódott, de a közel normális oxigenizáció mellett hypercapnia folyamatosan észlelhető volt. Átmeneti javulást követően kezelése során pneumónia alakult ki, szeptikus

1. TÁBLÁZAT. Pulmonalis hipertónia klasszifikációja (1)

1. Pulmonalis artériás hipertónia

1.1 Idiopátiás

1.2 Örökletes

1.3 Gyógyszerek és toxikus anyagok okozta $\mathrm{PH}$

\subsection{Asszociált $\mathrm{PH}$}

1.5 Pulmonalis venookkluzív betegség és/vagy pulmonalis kapilláris haemangiomatosis

2. Balszívfél-betegséghez társult $P H$

2.1 Szisztolés diszfunkció

2.2 Diasztolés diszfunkció

2.3 Billentyübetegségek

3. Tüdőbetegséghez és/vagy hypoxiához társult PH

3.1 COPD

3.2 Interstitialis tüdőbetegség

3.3 Egyéb tüdőbetegség kevert restriktív és obstruktív eltérésekkel

3.4 Alvási légzészavarok

3.5 Alveolaris hypoventiláció

3.6 Krónikus magaslati tartózkodás

3.7 Kongenitális tüdőbetegségek

4. Krónikus tromboembóliás pulmonalis hipertónia és egyéb pulmonalis artériás obstrukció

4.1 Krónikus tromboembóliás pulmonalis hipertónia

4.2 Egyéb pulmonalis artériás obstrukció

4.2.1 Angiosarcoma

4.2.2 Egyéb intravaszkuláris tumor

4.2.3 Arteriitis

4.2.4 Kongenitális pulmonalis artériás stenosis

4.2.5 Parazitainfekció

5. Tisztázatlan és/vagy multifaktoriális mechanizmusú $P H$

5.1 Hematológiai betegségek: krónikus hemolitikus anémia, myeloproliferatív betegség, splenectomia

5.2 Szisztémás betegségek: sarcoidosis, pulmonalis histiocytosis, lymphangioleiomyomatosis, neurofibromatosis

5.3 Metabolikus betegségek: glikogéntárolási-betegség, Gaucher-szindróma, Pajzsmirigybetegségek

5.4 Egyéb: pulmonalis tumoros trombotikus microangiopathia, fibrotizáló mediastinitis, krónikus veseelégtelenség, szegmentális pulmonalis hipertónia 


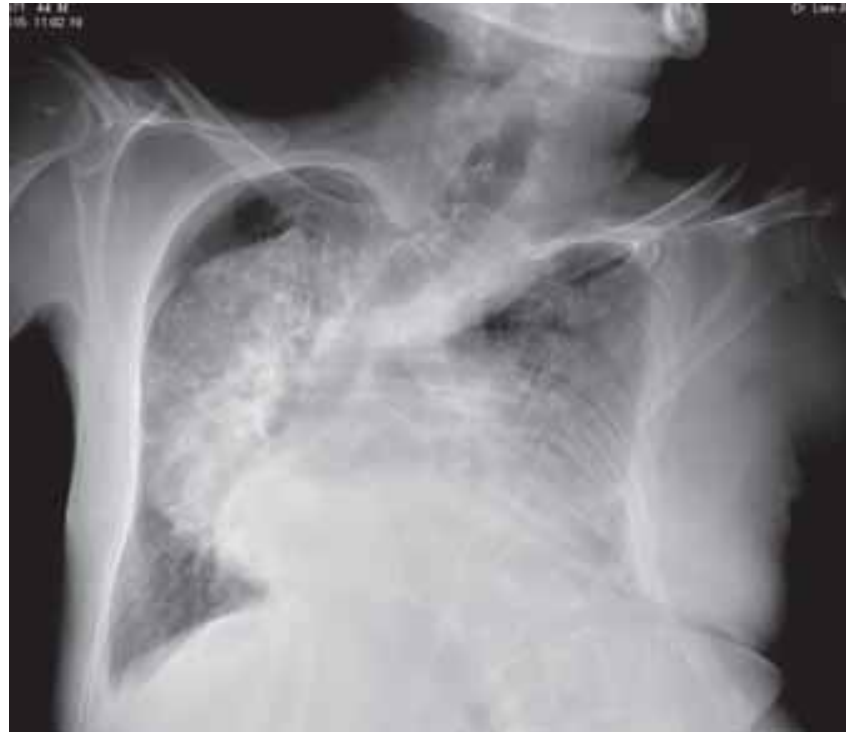

1. ÁBRA. Mellkasröntgen - súlyos mellkas- és gerincdeformitás, jelentős cardiomegalia

állapot miatt intenzív osztályra került, ahol átmenetileg invazív gépi lélegeztetésre is szorult. Invazív lélegeztetés és antibiotikum-terápia mellett a pneumónia szanálódott, az időközben kialakult pleurális folyadékot lecsapoltuk. Ekkor megfelelő oxigenizáció mellett normocapniát is el tudtunk érni. Az invazív gépi lélegeztetés megszüntetését követően ismételten NIV indult, amely mellett a $\mathrm{pCO}_{2}$-szint ismét emelkedett, de a felvételhez képest alacsonyabb szinten stabilizálódott. Légzésfunkciós vizsgálat a beteg általános állapota miatt csak a kezelés végén volt kivitelezhető és ez súlyos restriktív ventilációs zavart igazolt (3. táblázat).

A mellkasdeformitás a tüdőtranszplantációt kontraindikálta, így jobbszívfél-katéterezését nem tartottuk indokoltnak. Ugyanakkor az echoablak lehetővé tette, hogy a kezelés során a jobbszívfél-funkciót echokardiográfiával követni tudjuk. Már kezelése kezdetén a szinte folyamatosan alkalmazott NIV mellett a jobb- szívfél-terhelés jelentős mérséklődését tapasztaltuk, csökkent a ticuspidalis regurgitáció mértéke és sebessége, nagymértékben javult a becsült pulmonalis nyomás és a perctérfogat-emelkedés jeleként növekedett a bal kamrai kiáramlási görbe sebesség-integrálja (2. táblázat 2. oszlop). A jobbkamra-funkció javulása mellett a jobbszívfél-elégtelenség tünetei csökkentek, ödémáit kiürítette. Az invazív gépi lélegeztetés, az oxigenizáció teljes rendezése mellett a jobb kamra funkciója tovább javult, tartósan megfelelő hemodinamikai paramétereket észleltünk (2. táblázat 3. oszlop). Extubációt követőn a beteg állapotát napi 12-14 óra NIV-használat és intenzív légzési fizioterápia mellett sikerült stabilizálni. A vérgáz-vizsgálat során mérsékelt hypercapnia és kompenzált $\mathrm{pH}$ volt mérhető, az oxigén parciális nyomása a gépi lélegeztetéshez képest csökkent, de így is csaknem a normálértéken belüli maradt, echokardiográfiával a jobbszívfél-terhelés ismét kifejezettebbé vált, de a kezdeti szintre nem emelkedett (2. táblázat 4. oszlop). Az emellett beálított gyógyszeres kezeléssel (diuretikum, digitálisz) a szívelégtelenség tünetei már nem jelentkeztek. Tekintettel a restriktív légzési elégtelenséghez kapcsolt krónikus ventilációs és oxigenizációs zavarra, a betegnél nemcsak tartós oxigén, hanem tartós légzéstámogatás használata is indikált volt, így otthoni 10-14 óra NIV-használat javaslatával haza tudtuk bocsátani, az otthoni lélegeztetés felügyeletét a területileg illetékes intenzív osztály vállalta.

\begin{tabular}{|c|c|c|c|}
\hline & & Mért & $\%$ \\
\hline \multirow{5}{*}{$\begin{array}{l}\text { Légzés- } \\
\text { funkció }\end{array}$} & FVC (I) & 0,59 & 19 \\
\hline & $\mathrm{FEV}_{1}(\mathrm{I})$ & 0,57 & 21 \\
\hline & $\mathrm{FEV}_{1} / \mathrm{FVC}(\%)$ & 137 & \\
\hline & PEF (I/s) & 2,44 & 33 \\
\hline & IVC (I) & 0,52 & 16 \\
\hline
\end{tabular}

2. TÁBLÁZAT. Vérgáz és echokardiográfiás paraméterek változása a kezelés során (felvételkor, noninvazív lélegeztetés [NIV] és invazív lélegeztetés [IV] alatt)

\begin{tabular}{|c|c|c|c|c|c|}
\hline & & Felvétel & $\begin{array}{c}\text { NIV } \\
\text { kezelés 6. napja }\end{array}$ & $\begin{array}{c}\text { IV } \\
\text { kezelés 8. napja }\end{array}$ & $\begin{array}{c}\text { NIV } \\
\text { kezelés 28. napja }\end{array}$ \\
\hline \multirow{3}{*}{ Vérgáz } & $\mathrm{pH}$ & 7,29 & 7,31 & 7,49 & 7,41 \\
\hline & $\mathrm{pO}_{2}(\mathrm{Hgmm})$ & 67 & 73 & 109 & 85,3 \\
\hline & $\mathrm{pCO}_{2}(\mathrm{Hgmm})$ & 74,3 & 71 & 41,8 & 51,2 \\
\hline \multirow{6}{*}{ Echokardiográfia } & TAPSE $(\mathrm{mm})$ & 11 & 13 & 20 & 16 \\
\hline & IVRT (msec) & 138 & & & 58 \\
\hline & JK lat $\mathrm{S}^{\prime}(\mathrm{cm} / \mathrm{s})$ & 10,2 & & & 11,2 \\
\hline & TR (gr) & II-III & jelzett & jelzett & II \\
\hline & APSP $(\mathrm{Hgmm})$ & 76 & 38 & 44 & 67 \\
\hline & LVOT VTI (cm) & 8,2 & 16,8 & 15 & 14,9 \\
\hline
\end{tabular}




\section{Megbeszélés}

A hypoxiához társult $\mathrm{PH}$-val leggyakrabban krónikus tüdőbetegségek kapcsán találkozhatunk, de ezeken túl olyan egyéb, súlyos hypoxiát okozó kórképek mellett is megjelenhet, mint a súlyos mellkasdeformitásból adódó restriktív légzésfunkciós zavar. Ebben az esetben a betegek életkilátását alapvetően a rossz ventilációból és expectorálási nehézségből adódó légzési elégtelenség progressziójának üteme határozza meg.

A hypoxiához társult $\mathrm{PH}$-ban az alapvető ok a súlyos hypoxia, a ventilációs/perfúziós aránytalanság miatt kialakuló vazokonstrikció és a pulmonalis artériákat érintő remodelling, amely a PVR és a pulmonalis nyomás progresszív emelkedéséhez vezet. Ez a folyamat hoszszú távon jobbszívfél-nyomásterhelést okozva jobbkamra-elégtelenséget eredményezhet. Specifikus pulmonalis vazodilatátor kezelés ezekben az esetekben a ventilációs/perfúziós aránytalanság további romlását és a hypoxia súlyosbodását okozza, ezért ezek a szerek kontraindikáltak. Ezzel szemben a megfelelő oxigenizáció biztosítása, mint a pulmonalis hipertónia oki terápiája, már rövidtávon is a pulmonalis nyomás csökkenését és a jobbkamra-funkció és a hemodinamika javulást eredményezi (2).

Jobbszívfél-elégtelenség esetén a pozitív nyomású lélegeztetés az emelkedő intrathoracalis nyomás miatt csökkenti a jobb kamrai telödést, ami csökkent perctérfogatot és hemodinamikai instabilitást okoz. Esetünkben és más restriktív légzészavar talaján kialakult hypoxiához társult $\mathrm{PH}$-s betegeknél is megfelelően alacsony NIV nyomástámogatás és magas $\mathrm{FiO}_{2}$ mellett biztosítható olyan ventiláció, ami káros hemodinamikai következmények nélkül tud javítani az oxigenizáción (6). Ez már rövidtávon is a PVR csökkenését és a jobbszívfél-terhelés mérséklődését eredményezi, beindítva egy fokozatosan javuló hemodnamikai és légzési állapotot.
A súlyos mellkasdeformitással élő betegek esetén a tartós, otthoni noninvazív lélegeztetés jelenti a légzési elégtelenség adekvát kezelését és progressziójának mérséklését. Napi 10-14 óra NIV-használattal a betegek számára olyan elfogadható életminőség biztosítható, amely mellett a légzési elégtelenség súlyos, egyéb szervrendszert érintő hatásait mérsékelni lehet, keringésük kompenzált marad.

Az eset felhívja a figyelmet, hogy a mellkasdeformitás hemodinamikai következményeit tartós oxigénkiegészítéssel végzett légzéstámogatással mérsékelni lehet.

\section{Irodalom}

1. Galiè N, Humbert M, Vachiery JL, et al. Guidelines for the diagnosis and treatment of pulmonary hypertension: The Joint Task Force for the Diagnosis and Treatment of Pulmonary Hypertension of the European Society of Cardiology (ESC) and the European Respiratory Society (ERS): Endorsed by: Association for European Paediatric and Congenital Cardiology (AEPC), International Society for Heart and Lung Transplantation (ISHLT). Eur Heart J 2016 Jan 1; 37(1): 67-119. doi: doi: 10.1093/eurheartj/ehv317. Epub 2015 Aug 29

2. Zieliński J, Tobiasz M, Hawryłkiewicz I, et al. Long-term Oxygen Therapy on Pulmonary Hemodynamics in COPD Patients. Chest 1998; 113: 65-70.

3. Thabut G, Dauriat G, Stern JB, et al. Pulmonary hemodynamics in advanced COPD candidates for lung volume reduction surgery or lung transplantation. Chest 2005; 127: 1531-1536. doi: https://doi org/10.1378/chest.127.5.1531

4. Nadrous HF, Pellikka PA, Krowka MJ, et al. Pulmonary Hypertension in Patients With Idiopathic Pulmonary Fibrosis. Chest 2005; 128: 2393-9. doi: 10.1378/chest.128.4.2393

5. Ruggiero RM, Bartolome S, Torres F. Pulmonary hypertension in parenchymal lung disease. Heart Fail Clin 2012 Jul; 8(3): 461-74. doi: 10.1016/j.hfc.2012.04.010

6. Seeger W, Adir Y, Barberà JA, et al. Pulmonary hypertension in chronic lung diseases. J Am Coll Cardiol 2013 Dec 24; 62 (25 Suppl): D109-16. doi: 10.1016/j.hfc.2012.04.010

7. Shneerson JM, Simonds AK. Noninvasive ventilation for chest wall and neuromuscular disorders, Eur Respir J 2002; 20: 480-487. doi: 10.1183/09031936.02.00404002 